\title{
EFEKTIVITAS TARGET PEMBIAYAAN BAITUL MAAL WA TAMWIL SURYA GEMILANG DESA SEDAYULAWAS KECAMATAN BRONDONG KABUPATEN LAMONGAN
}

\author{
Abdul Muiz Hamid \\ Mahasiswa Program Studi S-1 Ekonomi Islam - Fakultas Ekonomi dan Bisnis - Universitas \\ Airlangga \\ Sri Herianingrum \\ Departemen Ekonomi Syariah - Fakultas Ekonomi dan Bisnis - Universitas Airlangga \\ Email: sriheria@yahoo.co.id
}

\begin{abstract}
This study aims to determine the effectiveness of targeted financing in BMT Surya Gemilang village Sedayulawas Brondong distridt of Lamongan through the financing to its customers and financial report statements, as well as the customers' trust in taking capital.

This study used a qualitative approach and descriptive case study. To collect the data, this study uses purposive sampling and snowball technique. The results of this study show that the effectiveness of targeted financing is annually achieved as planned by BMT Surya Gemilang. This is reflected in the provision of financing to customers and the financial reports which always reach the target as well as the smooth repayment of loans by customers.
\end{abstract}

Keywords: Effectiveness in Islam, Financing, Baitul Maal Wa Tamwil.

\section{PENDAHULUAN}

\section{A. Latar Belakang}

Munculnya Baitul Maal Wat Tamwil (BMT) yang memfokuskan kegiatan usahanya kepada pengusaha mikro, kecil dan menengah dapat memberikan dampak yang positif bagi para pengusaha, misalnya dengan peningkatan kesejahteraan keluarga pengusaha tersebut yang diakibatkan dari terpenuhinya modal usaha, sehingga usaha dapat berjalan dengan lancar seperti yang diharapkan. Sistem bagi hasil yang ditawarkannya juga menjadikan para pengusaha kecil menjadi leluasa bergerak dalam permodalan usaha mereka karena tidak terbebani akan adanya bunga yang terus bertambah. BMT dipandang sebagai salah satu alternatif sehubungan dengan usaha untuk memperjuangkan nasib pengusaha kecil. BMT dapat mengurangi atau meniadakan syarat-syarat yang dipandang memberatkan para pengusaha kecil dan menengah dalam memberikan pembiayaan.

BMT sendiri merupakan wadah kegiatan usaha simpan pinjam dalam membantu masyarakat atau anggota untuk mempermudah penambahan modal usaha, pembinaan produksi, pemasaran serta memperluas jaringan usaha yang dijalankan

Masyarakat atau anggota dalam cakupan luas pada umumnya membutuhkan dana bagi tiga kebutuhan utama mereka, yaitu kebutuhan siklus kehidupan (life cycles needs), kebutuhan darurat (emergency needs), dan kebutuhan untuk memanfaatkan peluang 
(opportunity needs). Efektifitas pembiayaan suatu lembaga keuangan mikro berbasis syariah dalam hal ini BMT menjadi satu hal yang mendesak terutama bagi masyarakat ekonomi lemah. Apabila efektifitas pembiayaan dapat dicapai maka akan berdampak positif bagi nasabah dan BMT itu sendiri. Meningkatnya kesejahteraan nasabah melalui peningkatan produksi, peningkatan pendapatan nasabah, peningkatan nilai aset, perbaikan rumah, mampu membuka usaha baru, peningkatan modal, dan peningkatan konsumsi. Bagi BMT yaitu terjaminnya keberlangsungan kegiatan pembiayaan karena perputaran modal lancar, sehingga penting kiranya dilakukan analisis efektivitas pembiayaan syariah pada Baitul Maal Wa Tamwil untuk dikaji.

Baitul Maal Wa Tamwil Surya Gemilang di kecamatan Brondong merupakan salah satu BMT di daerah yang menunjukan perkembangan dalam hal pembiayaan yang disalurkan. Berkembangnya BMT Surya Gemilang khususnya dibidang pembiayaan yang dijalankan, maka dibutuhkan suatu analisis tentang efektifitas target pembiayaan yang disalurkan oleh pihak BMT Surya Gemilang. Berdasarkan paparan diatas peneliti tertarik untuk melakukan penelitian dengan judul "Efektifitas Target Pembiayaan Baitul Mal Wa Tamwil Surya Gemilang Desa Sedayulawas Kecamatan Brondong Kabupaten Lamongan".

\section{B. Rumusan Masalah}

Berdasarkan uraian latar belakang diatas, rumusan masalah yang akan dibahas dalam penelitian ini adalah Bagaimana efektifitas target pembiayaan baitul maal wa tamwil surya Gemilang desa Sedayulawas kecamatan Brondong kabupaten Lamongan?

\section{Tujuan Penelitian}

Tujuan dari penelitian ini adalah untuk mengetahui efektifitas pembiayaan BMT Surya Gemilang di Desa Sedayulawas Kecamatan Brondong Kabupaten Lamongan.

\section{LANDASAN TEORI PENGEMBANGAN PROPOSISI}

DAN

\section{A. Landasan Teori}

"Baitul Maal Wa Tamwil merupakan lembaga kevangan mikro Islam yang terdiri dari dua istilah, yaitu

Baitul Maal dan Baitut Tamwil. Baitul Maal mengarah kepada kegiatan pengumpulan dan penyaluran dana yang bersifat non-profit seperti zakat, infaq dan shadaqah. Adapun Baitut Tamwil adalah pengumpulan dan penyaluran dana komersial" (Nurul Huda dan M. Heykal, 2010:363).

Sudarsono (2008:103) menjelaskan "Baitul Maal lebih mengarah pada usaha- usaha pengumpulan dan penyaluran dana nonprofit, seperti Zakat, Infaq dan Shodaqoh". Hal ini sesuai dengan yang dijelaskan Lubis (2004:114) "berkaitan dengan tugas Baitul Maal dilihat dari segi istilah fikih yang tujuannya untuk mengurusi kekayaan demi kepentingan umat. Sedangkan Baitut Tamwil sebagai usaha 
pengumpulan dan penyaluran dana komersial".

\section{B. Produk Pembiayaan Baitul Maal Wa Tamwil}

Suhendi (2009:3) menjelaskan produk penghimpunan dana yang di sediakan oleh BMT yang kemudian digunakan untuk pembiayaannya dapat didasarkan pada akad-akad tradisional Islam yakni (1) akad jual beli (2) akad sewa-menyewa (3) akad bagi hasil dan (4) akad pinjam meminjam. Sedangkan menurut Muhammad (2006:119) pembiayaan adalah suatu fasilitas yang diberikan bank Islam kepada masyarakat yang membutuhkan untuk menggunakan dana yang telah dikumpulkan oleh bank Islam dari masyarakat yang surplus dana.

Produk pembiayaan dapat diklasifikasikan menjadi beberapa fungsi. Klasifikasi pembiayaan dijelaskan Sudarsono (2008:1 10) sebagai berikut:

1. Perdagangan,

2. Industri rumah tangga,

3. Pertanian/peternakan/perikanan, dan lain sebagainya.

C. Efektifitas dalam Islam

Di dalam Islam, efektifitas merupakan suatu pencapaian tujuan atau sasaran secara tepat yang tujuan atau sasaran tersebut mencakup tujuan di dunia dan di akherat. Suatu perbuatan sebaiknya diawali dengan niat yang baik sehingga mencapai tujuan yang baik pula, efektifitas juga merujuk pada kemampuan untuk memiliki tujuan yang tepat, dan juga berhubungan dengan masalah bagaimana pencapaian tujuan atau hasil yang diperoleh, kegunaan, atau manfaat dari hasil yang diperoleh, tingkat daya fungsi unsur atau komponen serta tingkat kepuasan pengguna.

Dalam mencapai tujuan yang telah ditentukan tersebut, haruslah dilandasi dengan nilai-nilai Islam terutama kebenaran, kejujuran, keterbukaan, dan keahlian. Oleh karena itu seorang manajer haruslah memiliki empat sifat utama tersebut agar manajemen yang dijalankannya mendapatkan hasil yang maksimal. Seseorang, organisasi, maupun lembaga haruslah selalu bersungguh sungguh dalam melaksanakan sesuatu, terutama dalam mencapai tujuan atau sasaran yang telah

ditetapkan. Hal ini sesuai dengan AlQur'an surat Ash Sharh ayat 7.

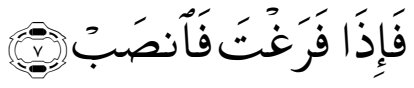

"Faidzā faraghta fanshab."

"Maka apabila kamu telah selesai (dari sesuatu urusan), kerjakanlah dengan sungguh-sungguh (urusan) yang lain". (QS, Ash Sharh:7).

(Maksudnya: sebagian ahli tafsir menafsirkan apabila kamu (Muhammad) telah selesai berdakwah Maka beribadatlah kepada Allah; apabila kamu telah selesai mengerjakan urusan dunia Maka kerjakanlah urusan akhirat, dan ada lagi yang mengatakan: apabila telah selesai mengerjakan shalat berdoalah). 


\section{Efektifitas Pembiayaan}

Pembiayaan adalah penyediaan vang atau tagihan yang dapat dipersamakan dengan itu, berdasarkan persetujuan atau kesepakatan antara bank dengan pihak lain yang mewajibkan pihak yang dibiayai untuk mengembalikan uang atau tagihan tersebut setelah jangka waktu tertentu dengan imbalan atau bagi hasil (UndangUndang Perbankan Nomor 10 tahun 1998). Menurut Noviandi (2009) dalam skripsinya menyatakan bahwa efektif atau tidaknya suatu penyaluran pembiayaan pada BMT dapat dinilai berdasarkan beberapa parameter antara lain: persyaratan peminjaman, prosedur peminjaman, realisasi kredit, besar kecilnya biaya administrasi, pelayanan petugas bank, lokasi bank, jaminan/agunan, pengetahuan dan partisipasi nasabah/calon nasabah, serta memberikan dampak positif.

Noviandi (2009) dalam skripsinya menyatakan bahwa suatu efektifitas pembiayaan dapat diukur dengan cara melihat kemantapan prosedur pembiayaan yang berdasarkan faktorfaktor sebagai berikut:

1. Jumlah nasabah yang menunjukkan bahwa sistem pembiayaan dapat diterima dan mampu menjangkau sasaran secara luas.

2. Keragaman mata pencaharian nasabah yang menunjukkan fleksibilitas prosedur pembiayaan yang dijalankan.
3. Frekuensi pinjaman nasabah, sebagai tingkat keseringan nasabah dalam mengambil pembiayaan.

4. Frekuensi tunggakan, sebagai tingkat keseringan nasabah dalam menunggak pembayaran dalam satu proses peminjaman .

5. Pelayanan pembiayaan, sejauh mana tingkat pelayanan yang dilakukan, mulai dari pengajuan pembiayaan sampai realisasi pembiaayaan.

\section{METODE PENELITIAN}

Penelitian menggunakan pendekatan kualitatif dan metode yang digunakan adalah studi kasus. Menurut Yin (2006: 18) pengertian penelitian studi kasus adalah sebuah metode penelitian yang secara khusus menyelidiki fenomena yang terdapat dalam konteks kehidupan nyata, yang dilaksanakan ketika batasanbatasan antara fenomena dan konteksnya belum jelas dimana multisumber bukti dimanfaatkan.

\section{A. Jenis dan Sumber Data}

Jenis data yang digunakan dalam penelitian ini adalah data primer dan data sekunder. Data primer dalam penelitian ini diperoleh dari hasil wawancara dan observasi langsung dengan pihak pengelola BMT Surya Gemilang maupun nasabah yang menerima pembiayaan dari BMT Surya Gemilang. Sedangkan data sekunder dalam penelitian ini diperoleh dari bukubuku, jurnal, internet yang berkaitan dengan BMT dan sumber-sumber lain yang relevan dengan penelitian. 


\section{B. Prosedur Pengumpulan Data}

Pengumpulan data dalam penelitian ini dilakukan dengan menggunakan enam sumber untuk menggali informasi yang meliputi dokumentasi, rekaman arsip, wawancara, observasi langsung, observasi partisipan, dan perangkat fisik yang ditujukan secara langsung pada objek penelitian yaitu BMT Surya Gemilang.

\section{Teknik Analisis}

Ada tiga teknik analisis yang digunakan dalam penelitian ini, yaitu analisis Proposisi Teoritis yang berfungsi untuk mengungkap secara teoritis mengenai proposisi yang telah dijelaskan, yaitu BMT Surya Gemilang sebagai lembaga keuangan syariah non bank mampu menciptakan efektifitas pembiayaan yang telah ditentukan oleh BMT Surya Gemilang. Kemudian teknik analisis deskriptif yang berfungsi untuk menguak segala fakta-fakta yang terungkap di lapangan dan disimpulkan secara jelas serta terperinci, mengenai efektifitas pembiayaan BMT Surya Gemilang. Teknik analisis yang terakhir yaitu Analisis Deret Waktu yang berfungsi untuk mengkaji permasalahan yang terjadi berdasarkan kurun waktu yang terjadi, melalui alur atau kronologis dan secara berurutan, sehingga dari awal hingga akhir dapat diketahui proses dari bagaimana keefektifitasan pembiayaan BMT Surya Gemilang.

\section{HASIL PENELITIAN DAN PEMBAHASAN}

\section{A. Gambaran Umum Subjek Penelitian}

1. Profil BMT Surya Gemilang
Sebagai organisasi bisnis yang dimilki dan dioperasikan oleh sekelompok masyarakat secara swadaya, Baitul Maal Wa Tamwil Surya Gemilang yang terletak di desa Sedayulawas kecamatan Brondong Kabupaten Lamongan mampu secara bersama- sama meningkatkan perekonomian masyarakat kecil diwilayah kecamatan Brondong. BMT Surya Gemilang dalam perjalanannya sejak tahun 1998 secara aktif membantu masyarakat melalui jasa keuangan syariah. Salah satunya yaitu dengan menyalurkan pembiayaan kepada para anggota dengan berbagai latar belakang bidang pekerjaan dan usahausaha informal lainnya.

Kunci sukses BMT Surya Gemilang dalam memberikan pembiayaan adalah dengan kejujuran dan itikat baik dari nasabah, agar pembiayaan yang diberikan berjalan dengan baik dan sesuai dengan yang diharapkan. Namun dalam prakteknya untuk dapat menilai apakah nasabah itu mempunyai kejujuran dan itikat baik itu sangat sulit. Oleh karenanya, sebelum memberikan pembiayaan kepada para nasabah, BMT akan melakukan analisa dengan sangat selektif dan hati-hati terhadap permohonan pembiyaan yang diajukan oleh calon nasabah penerima pembiayaan. Untuk melakukan penilaian, pada setiap pegawai BMT Surya Gemilang, khususnya bagian pembiayaan dituntut mempunyai kemampuan yang sangat handal dan jeli serta profesionalisme yang tinggi dalam menilai 
layak atau tidaknya BMT Surya Gemilang memberikan dana pembiayaan terhadap kegiatan usaha calon nasabah yang bersangkutan.

\section{B. Pembahasan}

1. Hasil Analisis dari Wawancara dengan Informan

Hasil dari informan 1 sampai 5 yang merupakan pimpinan dan pegawai BMT Surya Gemilang dapat diketahui bahwa setiap tahunnya target dari pembiayaan yang dicanangkan pihak BMT sudah dapat tercapai. Baik dari laporan keuangan maupun keberhasilan menyalurkan pembiayaan kepada anggota dalam mengembangkan usahanya. Sedangkan informan 6 sampai 8 merupakan para anggota BMT SuryaGemilang yang mendapatkan pembiayaan menyatakan merasa terbantu dengan pembiayaan yang diberikan oleh BMT Surya Gemilang, karena selain memberikan bantuan modal, Pihak BMT Surya Gemilang juga membantu dalam mengembangan usaha mereka, serta memberikan nilai-nilai Islami.

2. Keuangan BMT Surya Gemilang Dari laporan keuangan BMT Surya Gemilang dari tahun 2010 sampai 20112 diatas dapat diketahui, bahwa BMT Surya Gemilang terjadi peningkatan setiap tahunnya. Dari tahun 2010 yang mencatat aktiva dan pasiva sebesar Rp. 76.000.000 terjadi peningkatan pada tahun 2011 menjadi sebesar Rp. 105.020.000 dan meningkat lagi sebesar Rp. 108.575 .000 pada tahun 2012. Selain itu, pada laporan laba rugi BMT Surya Gemilang juga tercatat mengalami peningkatan dalam laba bersihnya. Laba bersih yang dihasilkan pada tahun 2010 yaitu sebesar Rp. 3.709.000. dan meningkat menjadi RP. 13.490.000 pada tahun 2011, kemudian pada tahun 2012 laba bersih yang dihasilkan oleh BMT Surya Gemilang menjadi Rp. 14.683.000.

Selain itu juga dapat dilihat dari target pembiayaan BMT Surya Gemilang telah mencapai. Hal ini dijelaskan pada table sebagai berikut:

Tabel 1.

Target Pembiayaan BMT Surya Gemilang 2010-2012

\begin{tabular}{|c|l|l|c|}
\hline Tahun & \multicolumn{1}{|c|}{ Target } & \multicolumn{1}{|c|}{ Realitas } & $\begin{array}{c}\text { Prosent } \\
\text { ase }\end{array}$ \\
\hline 2010 & $\begin{array}{l}\text { Rp. } \\
400.000 .000\end{array}$ & $\begin{array}{l}\text { Rp. } \\
444.000 .000\end{array}$ & $11 \%$ \\
\hline 2011 & $\begin{array}{l}\text { Rp. } \\
500.000 .000\end{array}$ & $\begin{array}{l}\text { Rp. } \\
519.480 .000\end{array}$ & $4 \%$ \\
\hline
\end{tabular}

Sumber : Hasil Pengolahan Data Primer, 2013 (diolah)

Dari tabel diatas dapat dijelaskan target pembiayaan pada awal tahun 2010 yang ditetapkan sebesar Rp. 400.000.000 dan realitasnya pembiayaan yang disalurkan BMT Surya Gemilang dapat dicapai sebesar Rp.444.000.000 atau $11 \%$ lebih besar dari target yang ditentukan. Kemudian ditahun 2011 BMT Surya Gemilang menetapkan target pembiayaan yang disalurkan sebesar Rp. 500.000.000 ternyata realitasnya pembiayaan yang disalurkan BMT Surya Gemilang tercapai sebesar Rp.519.480.000 atau $4 \%$ dana yang disalurkan lebih 
banyak dari target yang ditentukan. Tahun 2012 pihak BMT Surya Gemilang mencanangkan target pembiayaan yang disalurkan sebesar Rp.600.000.000, hasilnya realitas penyaluran pembiayaan di BMT Surya Gemilang sebesar Rp.607.791.000 atau $1.3 \%$ melebihi target pembiayaan yang ditentukan. Melihat tabel diatas dapat disimpulkan bahwa target pembiayaan yang ditetapkan di BMT Surya Gemilang dapat tercapai bahkan melebihi target yang sudah ditetapkan.

\section{Simpulan}

1. Baitul Maal Wa Tamwil Surya Gemilang dalam menjalankan kegiatan operasionalnya telah menjalankan pembiayaan secara efektif, hal ini dapat dilihat dari target atau hasil yang dicapai melalui laporan kevangan sebagai salah satu indikator efektifitas pembiayaan. Selain itu BMT Surya Gemilang juga sudah melakukan fungsifungsi dalam kelembagaan BMT mereka. Sebab salah satu ukuran dari efektifitas adalah terpenuhinya sasaran dan tujuan yang dicapai setiap tahun.

2. Tingkat efektifitas pembiayaan BMT Surya Gemilang juga berdampak pada para nasabah atau anggotanya akan kesadaran mereka dalam memenuhi syariat agama, seperti kewajiban membayar Zakat, Infaq, Shodaqoh. Karena dengan semakin berkembangnya usaha para anggotanya maka meningkat pula jumlah harta mereka. Serta pembinaan yang dilakukan oleh BMT Surya Gemilang terhadap nasabahnya menambah moral dan kreatifitas para nasabahnya dalam menngambangkan usahanya dengan disertai dengan nilai-nilai keagamaan yang diberikan oleh pihak BMT surya Gemilang.

\section{DAFTAR PUSTAKA}

Al-Qur'an dan Terjemahanya. 2005. Syamil Al Qur'an. Bandung: PT. Syaamil Cipta Media.

Andriani. 2005. BAITUL MAAL WAT TAMWIL Konsep dan Mekanisme di Indonesia,(Online), Volume 14, No.2,

http://idb2.wikispaces.com/file/vi ew/rd2012.pdf, diakses 14 April 2012).

Antonio, Muhammad Syafi'i. 2001. Bank Syariah: Dari Teori ke Praktik. Jakarta: Gema Insani Press.

--------. 2005. Manajemen Dana Bank Syariah, Edisi Pertama. Jakarta: Gema Insani Press.

Dewan Syariah Nasional MUI. 2000. Fatwa DSN MUI No. 04/DSNMUI/IV/2000 Tentang Murabahah.

------ . 2000. Fatwa DSN MUI No. 05/DSNMUI/IV/2000 Tentang Jual Beli Salam.

$\begin{array}{lll} & 2000 . \quad \text { Fatwa DSN } & \text { MUI No. } \\ \text { 06/DSN-MUI/IV/2000 } & \text { Tentang } \\ \text { Jual Beli Istishna'. } & \\ & 2000 . \quad \text { Fatwa DSN MUI No. } \\ \text { 07/DSN-MUI/IV/2000 } & \text { Tentang } \\ \text { Pembiayaan } & \text { Mudharanah } \\ \text { (Qiradh). }\end{array}$
(Qiradh). 
----- 2000. Fatwa DSN MUI No. 08/DSN-MUI/IV/2000 Tentang Pembiayaan Musyarakah.

------ . 2000. Fatwa DSN MUI No. 09/DSN-MUI/IV/2000 Tentang Pembiayaan ljarah.

----- 2001. Fatwa DSN MUI No. 19/DSNMUI/IV/2001 Tentang Al-Qardh.

------ . 2002. Fatwa DSN MUI No. 27/DSNMUI/III/2002 Tentang Al-ljarah AlMuntahiyah Bi Al-Tamlik.

Huda, Nurul dan M. Heykal. 2010. Lembaga Kevangan Islam: Tinjauan Teoretis dan Praktis. Jakarta: Prenada Media Group.

Ibnu Rusyd, Muhammad Ibnu Ahmad Ibnu Muhammad. 1988. Bidayatul Mujtihad wa Nihayatul Muqtashid. Beirut: Darul-Qalam.

IImi, Makhalul. 2002. Teori dan Praktek Lembaga Mikro Keuangan Syariah. Yogyakarta: UII Press.

Karim, Adiwarman. 2004, Bank Islam Analisis Fiqih dan Keuangan. Jakarta: PT. Raja Grafindo Persada.

Lubis, Suhrawardi. 2004. Hukum Ekonomi Islam. Jakarta: Sinar Grafika.

Muhammad. 2006. Bank Syariah Analisa Kekuatan, Kelamahan, Peluang dan Ancaman. Edisi Kedua. Yogyakarta: Ekonisia.

Noviandi, Bares Aulia. 2009. Analisis FaktorFaktor Pengambilan Pembiayaan dan Penilaian Efektifitas Pembiayaan Syariah Bagi Usaha Kecil pada BMT Dana Insani Kabupaten Gunung Kidul Propinsi
Yogyakarta. Skripsi tidak diterbitkan. Bogor. Fakultas Pertanian Institut Pertanian Bogor. Republik Indonesia. Peraturan Menteri Negara Koperasi dan Usaha Kecil dan Menengah Republik Indonesia No. 35.2/PER/M.KUKM/X/2007. 2007. (online),

(http://www.depkop.go.id/regula si/cat_view/34-regulasi/205-

peraturan-menteri-kjks-ujkskoperasi-2008.html diakses 2 Mei 2012)

Ridwan, $\quad$ Muhammad. 2004. Manajemen Baitul Maal Wat Tamwil (BMT). Yogyakarta: UII Press.

Sabiq, Sayyid. 1988. Fikih Sunnah 12. Bandung : PT Al-Ma'Arif.

Sakai, Minako \& Kacung Marijan. 2008. Mendayagunakan Pembiayaan Mikro Islami, (Online), (www.smeru.or.id/report/training/ menjembatani...dan.../73.pdf, diakses 14 Juli 2012)

Sudarsono, Heri. 2008. Bank \& Lembaga Keuangan Syariah Deskripsi dan Ilustrasi Edisi Ketiga. Yogyakarta: Ekonisia.

Suhendi, Hendi. 2009. Strategi Optimalisasi Peran BMT Sebagai Penggerak Sektor Usaha.

Syafar, Muhammad. 2006. Analisis Efektifitas Pembiayaan Sistem Syariah Terhadap Petani Agri Bisnis Sayuran pada Program UPK Ikhtiar Yayasan Perahu 
JESTT Vol. 1 No. 2 Februari 2014

Bogor. Skripsi tidak diterbitkan.

Bogor. Fakultas Ekonomi

Manajemen Institut Pertanian

Bogor.

Yin, Robert K. 2006. Studi Kasus: Desain dan Metode, Terjemahan. Jakarta: PT Grafindo Persada. 